\title{
Integrated Nutrient Management on Baby Corn (Zea mays L.)
}

\author{
A. Mahapatra ${ }^{1 *}$, A. K. Barik ${ }^{2}$ and G. C. Mishra ${ }^{3}$ \\ ${ }^{1,3}$ College of Agriculture, Bhubaneswar, OUAT, Odisha (751 003), India \\ ${ }^{2}$ Dept. of Agronomy, Visva-Bharati, PO-Sriniketan, Dist- Birbhum, West Bengal (731 236), India
}

\section{Corresponding Author}

A. Mahapatra

e-mail: anita.mahapatra100@gmail.com

\author{
Article History \\ Article ID: AR1855 \\ Received in 09 ${ }^{\text {th }}$ December, 2017 \\ Received in revised form 19 ${ }^{\text {th }}$ January, 2018 \\ Accepted in final form 02 ${ }^{\text {nd }}$ February, 2018
}

\begin{abstract}
An experiment on integrated nutrient management in baby corn was carried out during kharif and rabi seasons of 2012 and 2013 at Agronomic Main Research Station of Orissa University of Agriculture and Technology, Bhubaneswar, Odisha, India. The experiment was laid out in factorial randomized block design with three replications of each twenty treatment combinations consisting of four fertility levels and five secondary and micronutrient levels. Integrated nutrient management exhibited significant effect on growth, yield attributes and yield of baby corn. Application of $75 \%$ RDF+vermicompost @ $2.5 \mathrm{t} \mathrm{ha}^{-1}+$ mixed bio-fertilizers recorded the highest plant height, number of leaves plant ${ }^{-1}$, LAl , dry matter accumulation of baby corn at harvest along with yield baby corn ( $\left.1.50 \mathrm{t} \mathrm{ha}^{-1}\right)$ and green forage $\left(26.03 \mathrm{t} \mathrm{ha}^{-1}\right)$. Application of $40 \mathrm{~kg} \mathrm{Sha}^{-1}+5 \mathrm{~kg} \mathrm{Zn} \mathrm{ha}^{-1}+2.5 \mathrm{~kg} \mathrm{~B} \mathrm{ha}^{-1}$ has resulted in significant increase in yield components such as number of corns plant ${ }^{-1}$, length and girth of baby corn, baby corn weight along with yield of baby corn (1.54 t ha $\left.{ }^{-1}\right)$ and green forage $\left(26.17 \mathrm{t} \mathrm{ha} \mathrm{a}^{-1}\right)$. The highest net return ( $₹ 77921 \mathrm{ha}^{-1}$ ) and B: C ratio of 3.07 were registered in $75 \%$ RDF+vermicompost @ $2.5 \mathrm{t} \mathrm{ha}^{-1}+$ mixed bio-fertilizers. Application of 40 $\mathrm{kg} \mathrm{S} \mathrm{ha}^{-1}+5 \mathrm{~kg} \mathrm{Zn} \mathrm{ha}^{-1}+2.5 \mathrm{~kg} \mathrm{~B} \mathrm{ha}^{-1}$ resulted in highest net return (₹ $81217 \mathrm{ha}^{-1}$ ) and B: C ratio of 3.13.
\end{abstract}

Keywords: Baby corn, nutrient management, organic manures, S, Zn and B

\section{Introduction}

Maize (Zea mays L.) is the third most important cereal crop next to rice and wheat and has the highest production potential among the cereals. For diversification and value addition of maize as well as growth of food processing industries, recent development is of growing maize as 'baby corn'. It is a small young corn harvested at the stage of silk emergence. Baby corn has been used by Chinese as vegetable for generations and this practice has spread to other Asian countries. It is used as ingredient in most food preparations. It has nutritive value similar to that of non-legume vegetable such as cauliflower, tomato, cucumber and cabbage. Thavaprakash et al. (2005); Das et al. (2008) reported that 100 $\mathrm{g}$ baby corn contained $89.1 \%$ moisture, $0.2 \mathrm{~g}$ fat, $1.9 \mathrm{~g}$ protein, $8.2 \mathrm{mg}$ carbohydrate, $0.06 \mathrm{~g}$ ash, $28.0 \mathrm{mg}$ calcium, $86.0 \mathrm{mg}$ phosphorus, and $11.0 \mathrm{mg}$ of ascorbic acid. This vegetable has a great potential for cooking purposes and for processing as a canned product. Canned corn export to Thailand, Japan and Europe is increasing and has a good future. Young cob corn has a short growth thus a farmer can grow four or more crop cycles per year. It has a wide range of adaptation and does not need intensive cultivation. Considering these factors, baby corn has good potentials. Baby corn production, being a recent development has proved an enormously successful venture in countries like Thailand and Taiwan. Attention is now being paid to explore its potential in India, for earning foreign exchange besides higher economic returns to the farmers. Its cultivation is increasing in Meghalaya, western Uttar Pradesh, Haryana, Maharashtra, Karnataka and Andhra Pradesh (Ramachandrappa et al., 2004). Baby corn is a profitable crop that allows diversification of production, aggregation of value and increased income (Pandey et al., 2002). It is becoming popular among the growers in peri-urban areas in recent years due to its diverse utility and high net returns. Baby Corn when grown as sole crop produces significantly higher numbers of corns ha-1 and baby corn yield as well as gross return and return/rupee investment in comparison to other intercropping systems (Barik et al., 2016).

The agronomic requirement of baby corn is similar to grain maize except for a suitable variety, plant population density, higher doses of nitrogen and most importantly early harvesting. Yield and quality of baby corn are affected by cultural management applied to the maize plants especially fertilizer application. The different levels of nutrition of maize plants greatly affected the yield and quality (Kunushi et al., 1986). Long term fertilizer experiments have clearly visualized the negative impact of continuous use of chemical 
fertilizers on soil health (Yadav, 2003). The recent energy crisis and hike in prices of the inorganic fertilizers necessitate the use of organic manures and bio-fertilizers in crop production. The application of chemical fertilizer may assist in obtaining maximum production of baby corn but keeping in mind that chemical fertilizer may lead to hazardous effect on environmental health besides increasing production cost as such the judicious uses of fertilizers from different source will maintain the environmental health and sustainability (Dadarwal et al., 2009). However, the adoption of INM practices will reduce the production cost, thereby increasing the economic returns to the farmers and also increases the supply and availability of soil nutrients to the crop as well as increasing the activity of beneficial soil micro organism due to availability of more organic matter content. INM is required for augmenting and sustaining the productivity of any crop and cropping system (Nambiar and Ghosh, 1984; Prasad, 1999). In this context an attempt was made to augment baby corn cultivation by incorporation of FYM, vermicompost and sunhemp as green manure along with Sulphur, Zinc and Boron into the normal fertilizer input requirement. This study aims to evaluate the impact of integrated nutrient management on growth, yield and economics of baby corn cultivation.

\section{Materials and Methods}

The present study was carried out during kharif, 2012 and 2013 at Agronomy Main Research farm of Orissa University of Agriculture and Technology, Bhubaneswar, Odisha. The soil of the experimental block was sandy loam in texture, acidic in reaction, low in organic carbon, available $\mathrm{N}, \mathrm{K}, \mathrm{S}, \mathrm{Zn}$ and $B$ and medium in available $P$, The experiment was laid out in factorial randomized block design with three replications of each twenty treatment combinations consisting of four fertility levels and five secondary and micronutrient levels.

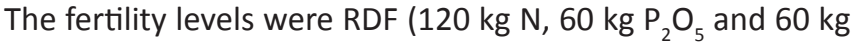
$\left.\mathrm{K}_{2} \mathrm{O} \mathrm{ha}{ }^{-1}\right), 75 \%$ RDF+FYM @ $5.0 \mathrm{t} \mathrm{ha}^{-1}+$ mixed bio-fertilizers (Azotobacter in combination with Azospirilum and PSM), 75 \% RDF + vermicompost @ 2.5 t ha $^{-1}+$ mixed bio-fertilizers and $75 \%$ RDF+green manuring with sunhemp+mixed biofertilizers. The five levels of secondary and micronutrients were no nutrient, $5 \mathrm{~kg} \mathrm{Zn} \mathrm{ha-1,40} \mathrm{kg} \mathrm{S} \mathrm{ha-1,} 40 \mathrm{~kg} \mathrm{~S} \mathrm{ha}^{-1}+5 \mathrm{~kg} \mathrm{Zn} \mathrm{ha}{ }^{-1}$ and $40 \mathrm{~kg} \mathrm{Sha}^{-1}+5 \mathrm{~kg} \mathrm{Zn} \mathrm{ha}{ }^{-1}+2.5 \mathrm{~kg} \mathrm{~B} \mathrm{ha}^{-1}$. The plant geometry was maintained at $40 \times 20 \mathrm{~cm}^{2}$ spacing in each experimental plot. The baby corn variety $\mathrm{VI}$ baby corn ${ }^{-1}$ was the test variety. Well decomposed FYM, vermicompost was applied at the time of land preparation. Sunhemp was grown as a green manure crop before baby corn crop. Full dose of phosphorus, potassium, sulphur, zinc, boron and half of nitrogen was applied as basal dose while remaining nitrogen was applied in two equal split applications at knee high stage and pretasseling stage. The source of N, P, K, Zn, S and B were Urea, Diammonium phosphate, Muriate of potash, Zinc EDTA, Elemental sulphur, and Borax respectively. All the cultural operations were performed as per the package of practices of maize. Observations on morphological traits were recorded for ten randomly selected plants while Baby corn yield and green fodder yield were recorded on plot basis. The raw data was subjected to appropriate statistical procedure as suggested by Gomez and Gomez (1984).

\section{Results and Discussion}

\subsection{Growth parameters}

Application of inorganic fertilizer in conjunction with organic manure (vermicompost and farm yard manure) and mixed bio fertilizers (Azotobacter, Azospirillum and PSB) influenced the crop growth. Highest plant height $(174.2 \mathrm{~cm})$ and number of leaves plant ${ }^{-1}$ (9.26) were recorded with $75 \% \mathrm{RDF}+2.5 \mathrm{t}$ vermicompost mixed with bio fertilizers (Azotobacter + Azosp irillum+Phosphorous solublizing bacteria). Similar favourable effect of $75 \%$ RDF+vermicompost mixed with bio fertilizers (Azotobacter+Azospirillum+PSB) in increasing the plant height of baby corn was noticed by Dadarwal et al., 2009. The highest LAl, dry matter production was in same trend as that of plant height and number of leaves plant ${ }^{-1}$. The LAI (4.11) and dry matter production (718.97 $\mathrm{g} \mathrm{m}^{-2}$ ) were observed with $75 \%$ RDF+2.5 t vermicompost ha ${ }^{-1}$ mixed with bio fertilizers. The higher plant height and large number of leaves plant ${ }^{-1}$ favoured higher canopy development under integrated nutrient management. It might have increased the light interception, absorption and utilization of solar radiation thus enhancing photosynthesis which was reflected in LAI and dry matter production. The reason for superior crop growth is due to synergistic effect of integration of inorganic fertilizers, organic manure and bio fertilizers that resulted in increased availability and absorption of nutrients through production of growth promoting substances and solubulization of nutrient by combined use of vermicompost mixed with bio fertilizers (Azotobacter, Azospirillium and PSB). It is in conformity with findings of several research workers (Thavaprakash and Velayudham, 2007; Dadarwal et al., 2009; Rasool et al., 2015). The integration of green manuring (sun hemp) with inorganic and bio fertilizers had no significant effect on crop growth which might be due to slow release of nutrients by decomposition of green manure biomass in short duration crop cycle of baby corn.

Application of secondary nutrient as sulphur combined with micronutrients (zinc and boron) increased the plant height and number of leaves plant ${ }^{-1}$. The highest plant height was recorded with combined use of $40 \mathrm{~kg} \mathrm{~S} \mathrm{ha}^{-1}+5 \mathrm{~kg} \mathrm{Zn} \mathrm{ha}^{-1}$ $(174 \mathrm{~cm})$ but highest number of leaves plant ${ }^{-1}$ (9.48) was recorded with $40 \mathrm{~kg} \mathrm{~S} \mathrm{ha}^{-1}+5 \mathrm{~kg} \mathrm{Zn} \mathrm{ha}^{-1}+2.5 \mathrm{~kg} \mathrm{~B} \mathrm{ha}^{-1}$. Crop growth in terms of LAI and dry matter $\mathrm{m}^{-2}$ was in similar trend as that of number of leaves plant ${ }^{-1}$. The highest LAI and dry matter accumulation in $40 \mathrm{~kg} \mathrm{~S} \mathrm{ha}^{-1}+5 \mathrm{~kg} \mathrm{Zn} \mathrm{ha}^{-1}+2.5$ $\mathrm{kg} \mathrm{B} \mathrm{ha}^{-1}$ were $4.21,699.11 \mathrm{~g} \mathrm{~m}^{-2}$. Sulphur as a constituent of succinyl coenzyme helps in chlorophyll formation which enhances meristematic activities promoting apical growth, 
plant height, leaf area and bio mass production (Kene et al., 1990). The profound increase in growth parameters was due to presence of zinc in auxin metabolism that leads to higher hormonal activity and growth performance. Zinc was also involved in synthesis of tryptophan needed for production of growth hormones like auxin and indole acetic acid which promotes enzyme activation and cell membrane integrity (Havlin et al., 2010). The boron had role in plant cell wall structure integrity and transport of water and nutrient and organic compounds, new growth and cell wall stability (Havlin et al., 2010). Application of sulphur, zinc and boron exerted the positive influence on all growth parameters of baby corn because soil of the experimental site was below the critical level. Application of sulphur with micronutrient $\mathrm{Zn}$ and $\mathrm{B}$ in deficient soil improved their availability and also uptake of other nutrients there by promoted growth and development. Similar favorable effect of Zinc and sulphur+Zinc (Kumar and Bohra, 2014) was noticed in baby corn by several workers.

\subsection{Yield and yield attributes}

The combined application of $75 \%$ RDF+organic manure as vermicompost @ $2.5 \mathrm{t} \mathrm{ha}^{-1}$ mixed with bio fertilizers remarkably augmented the yield attributes like number of cobs plant ${ }^{-1}(2.82)$, length of baby corn $(9.28 \mathrm{~cm})$, girth of baby corn $(4.99 \mathrm{~cm})$ and baby corn weight $(8.45 \mathrm{~g})$. It corroborated with the findings of Thavaprakash et al., 2005. Increase in yield attributes observed with integrated application of inorganic, organic and bio-fertilizers is due to improvement in crop growth parameters resulted in better translocation, utilization and partitioning of photosynthates. Moreover, improvement in soil physico-chemical and biological properties with integrated use of nutrients resulted in better availability, absorption and utilization of nutrients there by enhanced yield attributes (Table 1 ).

Integrated use of $75 \%$ RDF+organic manure in the form of vermicompost @ $2.5 \mathrm{t} \mathrm{ha}^{-1}$ mixed with bio fertilizers (Azotobacter, Azospirillum and PSB) increased the yield of baby corn $\left(1.50 \mathrm{t} \mathrm{ha}^{-1}\right)$ and green forage $\left(26.03 \mathrm{t} \mathrm{ha}^{-1}\right)$. It was in agreement with the findings of Thavaprakash et al., 2005; Dadarwal et al., 2009 and Rasool et al., 2015. The favorable effect of integrated nutrient supply in improving the yield components of baby corn resulted in enhancement of baby corn yield. Green cob yield was boosted with use of INM due to its favorable effect in increase in crop growth. The combined

\begin{tabular}{|c|c|c|c|c|c|c|c|c|c|c|}
\hline Treatments & $\begin{array}{l}\text { Plant ht. } \\
(\mathrm{cm} .)\end{array}$ & $\begin{array}{l}\text { No. of } \\
\text { leaves }\end{array}$ & LAI & $\begin{array}{c}\text { Dry } \\
\text { matter } \\
\left(\mathrm{g} \mathrm{m}^{-2}\right)\end{array}$ & $\begin{array}{l}\text { No. } \\
\text { of cobs } \\
\text { plant }^{-1}\end{array}$ & $\begin{array}{c}\text { Length } \\
\text { of baby } \\
\text { corn }\end{array}$ & $\begin{array}{c}\text { Girth } \\
\text { of baby } \\
\text { corn }\end{array}$ & $\begin{array}{c}\text { Wt. of } \\
\text { baby corn }\end{array}$ & $\begin{array}{l}\text { Yield } \\
\left(\mathrm{t} \mathrm{ha}^{-1}\right)\end{array}$ & $\begin{array}{l}\text { Green forage } \\
\text { yield }\left(\mathrm{t} \mathrm{ha}^{-1}\right)\end{array}$ \\
\hline \multicolumn{11}{|c|}{ Fertility levels } \\
\hline $\mathrm{F}_{1}$ & 173.1 & 9.17 & 4.00 & 657.63 & 2.76 & 9.17 & 4.84 & 8.23 & 1.44 & 25.59 \\
\hline $\mathrm{F}_{2}$ & 171.6 & 9.24 & 4.07 & 689.20 & 2.79 & 9.24 & 4.89 & 8.27 & 1.48 & 25.65 \\
\hline $\mathrm{F}_{3}$ & 174.2 & 9.26 & 4.11 & 718.97 & 2.82 & 9.28 & 4.99 & 8.45 & 1.50 & 26.03 \\
\hline $\mathrm{F}_{4}$ & 160.2 & 8.74 & 3.82 & 633.10 & 2.66 & 8.76 & 4.61 & 7.99 & 1.32 & 24.66 \\
\hline Sem \pm & 2.3 & 0.07 & 0.02 & 5.13 & 0.03 & 0.07 & 0.06 & 0.07 & 0.02 & 0.30 \\
\hline $\mathrm{CD}(p=0.05)$ & 6.8 & 0.20 & 0.06 & 15.17 & 0.08 & 0.22 & 0.18 & 0.21 & 0.07 & 0.88 \\
\hline \multicolumn{11}{|c|}{ Secondary and micronutrient levels } \\
\hline$M_{0}$ & 166.2 & 8.72 & 3.89 & 636.85 & 2.50 & 8.68 & 4.63 & 7.82 & 1.24 & 24.65 \\
\hline$M_{1}$ & 169.3 & 9.06 & 3.97 & 677.61 & 2.79 & 9.17 & 4.88 & 8.18 & 1.42 & 25.64 \\
\hline$M_{2}$ & 166.1 & 8.94 & 3.90 & 669.81 & 2.73 & 9.16 & 4.77 & 8.15 & 1.43 & 25.13 \\
\hline$M_{3}$ & 174.0 & 9.33 & 4.02 & 690.25 & 2.88 & 9.23 & 4.87 & 8.51 & 1.52 & 25.83 \\
\hline $\mathrm{M}_{4}$ & 173.3 & 9.48 & 4.21 & 699.11 & 2.88 & 9.32 & 5.01 & 8.53 & 1.54 & 26.17 \\
\hline Sem \pm & 2.6 & 0.08 & 0.02 & 5.73 & 0.03 & 0.08 & 0.07 & 0.08 & 0.03 & 0.33 \\
\hline $\mathrm{CD}(p=0.05)$ & NS & 0.22 & 0.07 & 16.96 & 0.09 & 0.24 & 0.20 & 0.23 & 0.08 & 0.99 \\
\hline \multicolumn{11}{|c|}{ Interaction (FxM) } \\
\hline Sem \pm & 5.2 & 0.15 & 0.05 & 11.46 & 0.06 & 0.16 & 0.13 & 0.16 & 0.05 & 6.71 \\
\hline $\operatorname{CD}(p=0.05)$ & NS & NS & 0.14 & NS & NS & NS & NS & NS & NS & NS \\
\hline
\end{tabular}

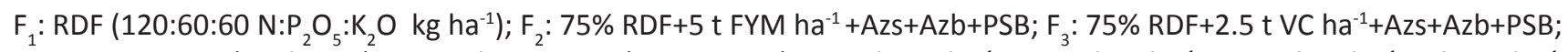
$F_{4}: 75 \%$ RDF+GM (Sunhemp)+Azs+Azb+PSB; $M_{0}$ : (No nutrient); $M_{1}: 5 \mathrm{~kg} \mathrm{Zn} \mathrm{ha}^{-1} ; M_{2}: 40 \mathrm{~kg} \mathrm{Sha}{ }^{-1} ; M_{3}: 40 \mathrm{~kg} \mathrm{Sha}^{-1}+5 \mathrm{~kg} \mathrm{Zn} \mathrm{ha}^{-1}$; $\mathrm{M}_{4}: 40 \mathrm{~kg} \mathrm{Sha}^{-1}+5 \mathrm{~kg} \mathrm{Zn} \mathrm{ha-1}+2.5 \mathrm{~kg} B$ ha- ${ }^{-1}$ RDF- Recommended dose of fertilizer, FYM: Farm yard manure; VC-Vermicompost, GM: Green manuring; Azs: Azospirillum; Azb: Azotobacter; PSB: Phosphorus solubilising bacteria 
effect of inorganic nutrient, organic manure (vermicompost) mixed with bio fertilizers had synergistic effect in availability of nutrient in soluble form throughout the growing period. However, enhancement of yield might be due to the effective utilization of applied nutrients thus increased sink capacity and higher nutrient uptake by crop.

The yield attributes of baby corn such as number of cobs plant $^{-1}(2.88)$, length of baby corn $(9.32 \mathrm{~cm})$, girth of baby corn $(5.01 \mathrm{~cm})$ and baby corn weight $(8.53 \mathrm{~g})$ were highest with application of $40 \mathrm{~kg} \mathrm{Sha}^{-1}+5 \mathrm{~kg} \mathrm{Zn} \mathrm{ha}^{-1}+2.5 \mathrm{~kg} \mathrm{~B} \mathrm{ha}^{-1}$ followed by $40 \mathrm{~kg} \mathrm{~S} \mathrm{ha}^{-1}+5 \mathrm{~kg} \mathrm{Zn} \mathrm{ha-1}$. The combined application of 40 $\mathrm{kg} \mathrm{S} \mathrm{ha}^{-1}+5 \mathrm{~kg} \mathrm{Zn} \mathrm{ha}^{-1}+2.5 \mathrm{~kg} \mathrm{~B} \mathrm{ha}^{-1}$ recorded the highest baby corn yield (1.54 tha-1) and green fodder yield of $26.17 \mathrm{t} \mathrm{ha}^{-1}$. It was followed by application of S @ 40 kg ha-1 $+Z n$ @ 2.5 kg $\mathrm{ha}^{-1}$ having the baby corn yield of $1.52 \mathrm{t} \mathrm{ha}^{-1}$ and green forage yield of $25.83 \mathrm{t} \mathrm{ha}^{-1}$. The improvement in yield attributes due to application of sulphur and micronutrient like $\mathrm{Zn}$ and $\mathrm{B}$ might be due to its favourable effect in increasing crop growth and better utilization and partitioning of food material which ultimately reflected in baby corn and green forage yield. This result was in pipeline with earlier work done by Kumar and Bhora, 2014.

\subsection{Economics}

Objective was to obtain highest return from the efficient and integrated use of inorganic nutrients, manures and bio fertilizers. The highest gross return of ₹ $115550 \mathrm{ha}^{-1}$ and net return of $₹ 77921$ ha $^{-1}$ were obtained with conjunctive use of $75 \%$ RDF+2.5 t vermi compost+mixed bio fertilizers. It was closely followed by 75\% RDF+FYM@ 5.0 t ha-1 +mixed bio fertilizers. The $\mathrm{B}$ : $\mathrm{C}$ ratio was highest in RDF followed by 75\% RDF+FYM @ 5.0 t ha ${ }^{-1}+$ mixed biofertilizers. Increase in baby corn and green forage yield coupled with appreciable cost of cultivation registered the better return. Similar line of result was reported earlier by different workers (Dadarwal et al., 2009 and Kumar and Bhora, 2014). Application of $40 \mathrm{~kg} \mathrm{~S} \mathrm{ha}^{-1}$ in combination with $5 \mathrm{~kg} \mathrm{Zn} \mathrm{ha}^{-1}+2.5 \mathrm{~kg} \mathrm{~B} \mathrm{ha}^{-1}$ registered the highest gross return ( $\left.₹ 119292 \mathrm{ha}^{-1}\right)$, net return ( $₹ 81217$ ha $^{-1}$ ) and B: C ratio (3.13). The next best result was obtained with combination of $40 \mathrm{~kg} \mathrm{~S} \mathrm{ha}^{-1}+5 \mathrm{~kg} \mathrm{Zn} \mathrm{ha}^{-1}$. The enhancement in economics of baby corn with integrated use of RDF+vermicompost and micronutrient was reported earlier by Ashoka et al., 2008. Kumar and Bhora, 2014 also obtained the favourable effect of $\mathrm{S}+\mathrm{Zn}$ in increasing the economics of baby corn (Table 2).

\begin{tabular}{|c|c|c|c|c|}
\hline Treatments & Cost of cultivation (₹ ha-1) & Gross return (₹ ha-1) & Net return (₹ ha-1) & Benefit: Cost ratio \\
\hline \multicolumn{5}{|c|}{ Fertility levels } \\
\hline $\mathrm{F}_{1}$ & 35654 & 111913 & 76259 & 3.14 \\
\hline $\mathrm{F}_{2}$ & 36619 & 113950 & 77331 & 3.11 \\
\hline $\mathrm{F}_{3}$ & 37629 & 115550 & 77921 & 3.07 \\
\hline $\mathrm{F}_{4}$ & 35379 & 104160 & 68781 & 2.94 \\
\hline Sem \pm & - & 1432 & 1432 & 0.04 \\
\hline $\operatorname{CD}(p=0.05)$ & - & 4238 & 4238 & 0.12 \\
\hline \multicolumn{5}{|c|}{ Secondary and micronutrient levels } \\
\hline$M_{0}$ & 34444 & 99304 & 64860 & 2.88 \\
\hline$M_{1}$ & 35504 & 111813 & 76309 & 3.15 \\
\hline $\mathrm{M}_{2}$ & 36169 & 110183 & 74015 & 3.04 \\
\hline $\mathrm{M}_{3}$ & 37410 & 116375 & 78965 & 3.11 \\
\hline$M_{4}$ & 38075 & 119292 & 81217 & 3.13 \\
\hline Sem \pm & - & 1601 & 1601 & 0.04 \\
\hline$C D(p=0.05)$ & - & 4737 & 4738 & 0.14 \\
\hline \multicolumn{5}{|c|}{ Interaction (FxM) } \\
\hline Sem \pm & - & 3202 & 3202 & 0.09 \\
\hline $\operatorname{CD}(p=0.05)$ & - & NS & NS & NS \\
\hline
\end{tabular}

\section{Conclusion}

The integrated application of 75\% RDF+vermicompost @ 2.5 t ha-1 ${ }^{-1}$ mixed bio-fertilizers remarkably increased the crop growth, yield components and yield of baby corn $(1.50 \mathrm{t}$ $\left.\mathrm{ha}^{-1}\right)$ and green forage $\left(26.03 \mathrm{t} \mathrm{ha}^{-1}\right)$. Highest gross return of Rs. 115550/ha and net return of ₹ $77921 \mathrm{ha}^{-1}$ were obtained from the same treatment. Application of $40 \mathrm{~kg} \mathrm{~S} \mathrm{ha}^{-1}+5 \mathrm{~kg} \mathrm{Zn}$ $\mathrm{ha}^{-1}+2.5 \mathrm{~kg} \mathrm{~B} \mathrm{ha}^{-1}$ significantly influenced the crop growth, yield components, yield of baby corn and green forage yield along 
with highest gross return, net return and $\mathrm{B}: \mathrm{C}$ ratio.

\section{References}

Ashoka, P., Pujari, B.T., Hugar, P.S., Desai, B.K., 2008. Effect of Micronutrients With or Without Organic Manures on Yield of Baby Corn (Zea mays L.)-Chickpea (Cicer artietinum L.) Sequence. Karnataka Journal of Agricultural Science 21(4), 485-487.

Barik, A.K., Karmakar, M., Ghorai, S.K., 2016. Studies on the effect of crop geometry and nutrient management on productivity and economics of baby corn and cowpea (fodder) intercropping system. International Journal of Bioresource and Stress Management 7(2), 305-309

Dadarwal, R.S., Jain, N.K., Singh, D., 2009. Integrated Nutrient Management in Baby Corn (Zea mays). Indian Journal of Agricultural sciences 79(12), 1023-1025.

Das, S., Yadav, V.K., Jat, M.L., Asha, K., Sujay, R., Jyoti, K., Sekhar, J.C., 2008., Baby corn in India. DMR Technical Bulletin.2008. (1-45). Directorate of Maize Research, Pusa Campus, New Delhi.

Gomez, K.A., Gomez, A.A., 1984. Statistical Procedure for Agricultural Research. John -Wiley and Sons Inc., New York, 680.

Kene, H.K., Wankhade, S.T., Sagare, B.N., 1990. Influence of nutrient spray on yield and nutrient content of sunflower (Helianthus annus L). Annals of Plant Physiology 4(2), 251-253.

Kumar, R., Bohra, J.S., 2014. Effect of NPKS and Zn application on growth, yield, economics and quality of baby corn. Archives of Agronomy and soil science 60(9), 1193-1206.

Kunushi, H.M., Bandel, V.A., Nulford, F.R., 1986. Seasonal $P$ uptake of corn under No till and conventional till.
Management Press, 293-296.

Nambiar, K.K.M., Ghosh, A.B., 1984. Highlights of research of long term fertilizer experiments in India (1971-82). LTFE Research Bulletin No.1, 100.

Ramachandrappa, B.K., Nanjappa, I.I.V., Shivkumar, I.I.K., 2004. Yield and quality of baby corn (Zea mays L.) as influenced by spacing and fertilization levels. Acta Agronomica Hungarica 52, 237-243.

Prasad, B., 1999. Conjuctive use of fertilizer with organic, crop residues and green manuring for their efficient use in sustainable crop production. Fertiliser News 44(5), 67-73.

Pandey, A.K., Mani, V.P., Prakash, V., Singh, R.D., Gupta, H.S., 2002. Effect of varieties and plant densities on yield, yield attributes and economics of baby corn (Zea mays). Indian Journal of Agronomy 47, 221-226.

Rasool, S., Kanth, R.H., Hamid, S., Raja, W., Alie, B.A., Dar., Z.A. 2015. Influence of Integrated nutrient management on growth and yield of sweet corn (Zea mays L. Saccharata) under temperate conditions of Kashmir valley. American Journal of Experimental Agriculture 7(5)315-325.

Thavaprakaash, N., Velayudham, K., Muthukumar, V.B., 2005. Effect of Crop geometry, Intercropping Systems and Integrated Nutrient Management Practices on Productivity of Baby Corn (Zea mays L.) based Intercropping Systems. Research Journal of Agricultural and Biological Sciences 1(4), 295-302.

Thavaprakash, N., Velayudham, K., 2007. Effect of crop Geometry, Intercropping systems and INM practices on cob yield and nutrient uptake of baby corn. Asian Journal of Agricultural Research 1(1), 10-16. 